\title{
Screening the APC, MLH1, MSH2 and TP53 Mutations in Patients with Early Onset of Colorectal Cancer
}

Leyla Djansugurova ${ }^{1}$, Gulnur Zhunussova ${ }^{1,3}$, Elmira Khussainova ${ }^{1}$, Olzhas Iksan ${ }^{1}$, Georgiy Afonin ${ }^{2}$, Dilyara Kaidarova ${ }^{2}$, Marco Matejcic $^{3}$ and M. Iqbal Parker $^{3}$

${ }^{1}$ Laboratory of Molecular Genetics, Institute of General Genetics and Cytology, Kazakhstan

${ }^{2}$ Almaty Oncology Centre, Almaty 050060, Kazakhstan

3International Centre for Genetic Engineering and Biotechnology (ICGEB), Cape Town Component, and Medical Biochemistry/IDM, UCT, Observatory, Cape Town, South Africa

*Corresponding author: Professor Leyla Djansugurova, Laboratory of Molecular Genetics, Institute of General Genetics and Cytology, Republic of Kazakhstan, Almaty, 050060, Al-Farabi ave, 93, Kazakhstan, Tel:+77272695014; Fax: +77272694587; E-mail: leylad@mail.ru

Received date: Sep 30, 2014, Accepted date: Oct 25, 2014, Published date: Oct 30, 2014

Copyright: (c) 2014 Djansugurova L, et al. This is an open-access article distributed under the terms of the Creative Commons Attribution License, which permits unrestricted use, distribution, and reproduction in any medium, provided the original author and source are credited.

\begin{abstract}
Objective: A molecular-genetic study of early onset colorectal cancer (CRC) patients in Kazakhstan.

Methods: The direct sequencing of crucial regions of key CRC genes (APC codons between nucleotides 967-1386 and 1286-1513; exons 8 and 16 of MLH1 and exon 7 of MSH2; exons 5-9 of TP53) was performed for early cancer-onset and suspected familial cases.

Results: Blood was collected from 249 patients diagnosed with rectal or colon cancer. There were 32 patients with early onset CRC (28-50 yrs), including 10 patients with a family history of cancer. Two types of nucleotide replacements were detected in intron 4 (c.376-19C>T) and intron 9 (c.993+12T>C) of TP53, both in the heterozygous state. Another nucleotide substitution was present in 15 patients in intron 15 of MLH1 (c.1732-90C>A) while known coding polymorphisms were observed in exon 8 of MLH1 (rs1799977-A655G/lle219Val), in exon 7 of MSH2 (rs5028341-C1168T/Leu390Phe), in exon 15 of APC (rs1801166-G3949C/p.Glu1317GIn and rs41115$4479 \mathrm{G}>\mathrm{A}$ ). The single deletion, c.3613delA (p.Ser1205fs), located in exon 15 of APC gene, was found in the heterozygous state in two patients with a family history of adenomatous polyposis.
\end{abstract}

Conclusion: We suggest a possible role of MLH1 655A>G, MSH2 1168C>T, APC 4479G>A, and APC 3949G>C polymorphisms in the susceptibility to early onset of CRC. A single base pair deletion at codon 1205 (c.3613delA) of APC gene seems to be differentially associated with early-onset cases depending on having a family history of CRC.

Keywords: Mutations and polymorphisms; Tumor suppressor genes; DNA mismatch repair genes; Adenomatous polyposis; Deletion of APC

\section{Introduction}

Colorectal cancer (CRC) continues to be one of the most common fatal types of cancer with more than 1.5 million new cases being recorded worldwide every year and around $50 \%$ of patients dying from the disease [1]. In Eurasian countries, Kazakhstan is has the seventh highest incidence of colorectal cancer. Most cases are diagnosed at a very late stages of cancer progression (stages III-IV), when treatment is expensive and inefficient.

CRC is age related, colonic cancer more so than rectal, with the incidence peaking within the range 50-70 years and a higher incidence in men than in women. The median age at diagnosis is about 70 years in developed countries and about 60 in developing countries. In recent years there has been considerable worldwide increase in CRC morbidity and a significant rejuvenation of this cancer. The possible reason is lifestyle change such as lack of exercise, poor nutrition due to increased fast food consumption and increased smoking and alcohol consumption habits among young people.
The disease develops slowly over several years and progress through distinct cytological changes ranging from single crypt lesions through adenoma to malignant carcinoma with the potential for invasion and metastasis. Adenoma, diffuse polyposis and nonspecific ulcerative colitis increase the risk of cancer development and have been considered as precancerous states. Thus, diffuse polyposis malignancy occurs in almost $100 \%$ cases.

This is one of the diseases for which preventive measures are most effective. Although screening and early detection have been shown to reduce CRC incidence and mortality, organized screening programs are still to be implemented in many countries. Primary prevention aims to identify germline mutations associated with high cancer risk. Secondary prevention of cancer is aimed at screening relatives of probands, the identification of families with a history of cancer burden, followed by medico-genetic counseling and clinical examination of high risk individuals. While this is the only approach to the organization and functioning of a preventive program for hereditary forms of cancer, it is unfortunately still far from being implemented in Kazakhstan. However, the National Screening Program for malignant neoplasms of the colon and rectum was initiated in 2011. 
Colorectal carcinogenesis is characterized by the successive accumulation of mutations in genes controlling epithelial cell growth and differentiation, leading to genomic instability and the widespread perpetuation of loss of DNA integrity. The classic model of colorectal tumorigenesis includes several genetic changes that are required for cancer initiation and progression. The earliest genetic trigger is the inactivation of the APC (adenomatous polyposis coli) pathway followed by mutations in other tumor suppressor genes (APC, SMAD2, SMAD 4, DCC, TP53) and oncogenes (KRAS) and several other genes/pathways that accompany the transitions in pathology that drive the tumor towards malignancy and metastasis. In parallel with gene mutations, there is a deregulated expression of oncogenes and/or tumor suppressor genes as a consequence of epigenetic modifications of their promoters. The spectrum of mutated genes in colorectal cancer is not limited to these genes. Thus, the analysis of sequencing results of 13023 genes in 11 colorectal cancers revealed that individual tumors accumulate 177 mutations in 105 genes. Validation screening has shown that on average only 11 gene mutations per tumor were sufficient to drive the neoplastic process [2].

The choice of candidate-genes in this study was based on wellknown associations of a limited number of genes implicated in the etiology and pathogenesis of CRC [3-9]. Numerous of molecular epidemiological studies have been devoted to identifying biomarkers for sporadic and familial colorectal cancers. Different molecular mechanisms underlying development of familial syndromes predisposing to CRC have already been defined [1,10-15].

In spite of the fact that the majority of CRCs cases are sporadic, the percentage of patients with familial histories of cancer is $20-30 \%$. Various studies have shown that $15-20 \%$ of patients with CRC have first-degree relatives suffering from the same type of cancer [1, 10-16]. The most common form of familial CRC is hereditary nonpolyposis colorectal cancer (HNPCC or Lynch syndrome), which manifests with high mortality rates. HNPCC is associated with mutations in genes encoding proteins involving in DNA mismatch repair (MMR) such as mutations in the hMLH1, hMSH2, hPMS2, or hMSH6 genes. To date, more than 240 mutations have been described, with the vast majority occurring in either hMLH1 (60\%) or hMSH2 (35\%) [9-11,15,17].

There are many genetic syndromes associated with a predisposition to the occurrence of a large number of polyps in the colon - familial adenomatous polyposis (FAP), attenuated FAP (AFAP), MUTYHassociated polyposis (MAP). FAP is characterized by the development of hundreds to thousands of adenomas throughout the entire colon and rectum, which if not removed will almost certainly result in the development of colorectal cancer. Inactivation of both copies (alleles) of APC gene located on chromosome 5 constitutes an early, and possibly the very first event in colorectal tumorigenesis. The majority of mutations occur in APC tumor suppressor gene within a section of the gene known as the mutation cluster region bounded by codons 1286 and $1513[3,4,14,15,17]$.

Rare syndromes include hamartomatous polyposis conditions (Peutz-Jeghers syndrome (PJS), juvenile polyposis syndrome (JPS) and hyperplastic polyposis). Associated with CRC syndromes are inherited primarily in an autosomal dominant pattern, with the exception of MAP, which is inherited in an autosomal recessive manner. These conditions suggest the development of CRC in combination with other tumor locations.

For investigation of individuals with early onset CRC and suspected family history the following genetic regions were chosen: 1) APC tumor suppressor gene mutations, associated with FAP - 5q deletions in exon 15 [3,4]; 2) MLH1 DNA mismatch repair gene mutations in exons 8 and 16 associated with Lynch syndrome [5,9]; 3) MSH2 exon 7 DNA mismatch repair gene mutations associated with Lynch syndrome [5,9]; and 4) TP53 exon 5-9 mutations associated with malignancy $[6,8]$.

\section{Materials and Methods}

\section{Sampling}

Blood samples were collected from 249 patients diagnosed with CRC in Almaty Oncology Centre (Almaty, Kazakhstan) after receiving informed consent from the patients. Detailed questionnaires and informed consents were filled prior collection of samples. The questionnaire included information about socio-demographic status, dietary factors, occupation, tobacco/alcohol habits, previous illness, illnesses of relatives, radiation exposure etc. The study protocol was approved by the Ethics Committee of the Asfendiyarov Kazakh National Medical University (Almaty, Kazakhstan).

\section{DNA isolation}

Genomic DNA was isolated from peripheral blood leukocytes using the standard phenol-chloroform method with modifications in the composition of the lysis buffer to contain $0.2 \mathrm{M}$ sodium acetate and $1 \%$ sodium dodecyl sulphate, $\mathrm{pH}$ 8.0. The DNA was dissolved in distilled water and quantity and quality of the DNA was evaluated by spectrophotometric analysis (NanoDrop 2000, Thermo Scientific). The extracted DNA samples were stored at $-20^{\circ} \mathrm{C}$ until further use.

\section{Direct sequencing}

Direct sequencing was used to screen for mutations in critical regions associated with CRC: exon 15 (codons 967-1386 and 1286-1513) of the APC gene [3,4]; exons 8 and 16 of the MLH1 gene; exon 7 of the MSH2 gene [5,9]; and exons 5-9 of TP53 [6,7].

All specific primers except primers for amplification of TP53 gene exons 5-9 were designed by using NCBI Primer Blast, Primer3 and IDT OligoAnalyser software. To amplify exons 5-9 of the TP53 gene we used the primers and protocols described in the IARC TP53 database. Amplification reactions were carried out in a final volume of $20 \mu$, containing 50-100 ng of genomic DNA, 1xPCR buffer, $0.2 \mathrm{mM}$ of each dNTP, $1.5 \mathrm{mM} \mathrm{MgCl}_{2}, 0.4 \mu \mathrm{M}$ of each primer, and 0.5 unit of FastStart Taq DNA polymerase (Roche, Switzerland). PCR was performed using the Veriti ${ }^{\text {'m }}$ Dx 96-well Thermal Cycler (Applied Biosystems, USA) and the amplified products were visualized by electrophoresis in ethidium-bromide-stained $1.5 \%$ agarose gels. The sequences of specific primers and PCR details are shown in Table 1.

DNA sequencing was performed using an automated ABI 3730xl Genetic Analyzer (Applied Biosystems, USA). PCR products were purified using the Nucleofast 96 well PCR plate (Macherey-Nagel, Germany). The protocols supplied by the manufacturer are implemented on a Tecan EVO150 robotic workstation. The sequencing reactions were performed using specific primers (Table 1) and the BigDye Terminator v3.1 sequencing kit (Applied Biosystems, USA). The cycle sequencing reactions were as follows: 50-100 nmol of purified PCR products, $2 \mu \mathrm{l}$ of BigDye Terminator, $1 \mu \mathrm{l}$ of Sequencing Buffer, 3.2 pmol of primer in a total volume of $20 \mu$ l. Cycle sequencing was performed using 55 cycles consisted of $96^{\circ} \mathrm{C}$ at $5 \mathrm{~min}, 60^{\circ} \mathrm{C}$ at 5 
Page 3 of 9

min and $96^{\circ} \mathrm{C}$ at $5 \mathrm{~min}$. After cycle sequencing the products were treated by SDS, then transferred onto Sephadex columns using a Tecan EVO150 (Agilent Technologies, USA) and centrifuged. The purified sequencing products were dried using a heated vacuum drier and resuspended in Hi-Di (Life Technologies, USA). Prior to sequencing electrophoresis the samples were denatured at $95^{\circ} \mathrm{C}$ for 2 minutes. Directly after heating the samples were placed on ice for 5 minutes. Electrophoresis was performed on an ABI 3730xl using a $50 \mathrm{~cm}$ capillary array and POP7 (supplied by Applied Biosystems, USA).

\begin{tabular}{|c|c|c|c|}
\hline $\begin{array}{l}\text { Amplifie } \\
\text { d } \\
\text { regions }\end{array}$ & $\begin{array}{l}\text { Primer pairs } \\
\left(5^{\prime} \rightarrow 3^{\prime}\right)\end{array}$ & PCR conditions & $\begin{array}{l}\text { Length of } \\
\text { PCR } \\
\text { products }\end{array}$ \\
\hline $\begin{array}{l}\text { Exon } 16 \\
\text { of } M L H 1 \\
\text { gene }\end{array}$ & $\begin{array}{l}\text { f-GGGGTTTTGTTGTGGATTGT } \\
\text { r-CTAGTCCTGACCTTGGAACG }\end{array}$ & \multirow{5}{*}{$\begin{array}{l}\text { Initiation } \\
\text { denaturation step at } \\
95 \circ \mathrm{C} \text { for } 10 \text { min, } \\
\text { followed by } 30 \\
\text { cycles of } 95 \circ \mathrm{C} \text { for } \\
30 \mathrm{sec}, 58 \mathrm{oC} \text { for } 30 \\
\mathrm{sec}, 72^{\circ} \mathrm{C} \text { for } 1 \mathrm{~min} \\
30 \mathrm{sec} \text { and final } \\
\text { elongation step at } \\
720 \mathrm{C} \text { for } 7 \text { min. }\end{array}$} & $700 \mathrm{bp}$ \\
\hline $\begin{array}{l}\text { Exon } 8 \text { of } \\
\text { MLH1 } \\
\text { gene }\end{array}$ & $\begin{array}{l}\text { f- } \\
\text { CTCAGCCATGAGACAATAAAT } \\
\text { C } \\
\text { r- } \\
\text { GGTTCCCAAATAATGTGATGG }\end{array}$ & & $217 \mathrm{bp}$ \\
\hline $\begin{array}{l}\text { Exon } 7 \text { of } \\
\text { MSH2 } \\
\text { gene }\end{array}$ & $\begin{array}{l}\text { f- } \\
\text { GCTGATTTAGTTGAGACTTAC } \\
\text { GTGC } \\
\text { r- } \\
\text { TCTGAATGTGTCCTAAGAGTG } \\
\text { AGT }\end{array}$ & & $401 \mathrm{bp}$ \\
\hline $\begin{array}{l}\text { Exon } 15 \\
\text { of } A P C \\
\text { gene } \\
\text { (codons } \\
967-1386 \\
\text { ) }\end{array}$ & $\begin{array}{l}\text { f- } \\
\text { AGTAGTAGTGATGGTTATGGT } \\
\text { r-CATCTGCTAAACATGAGTGG }\end{array}$ & & $1260 \mathrm{bp}$ \\
\hline $\begin{array}{l}\text { Exon } 15 \\
\text { of } A P C \\
\text { gene } \\
\text { (codons } \\
1286- \\
1513 \text { ) }\end{array}$ & $\begin{array}{l}\text { f- } \\
\text { GAAATAGGATGTAATCAGACG } \\
\text { r-CATTCCCATTGTCATTTTCC }\end{array}$ & & $751 \mathrm{bp}$ \\
\hline $\begin{array}{l}\text { Exons } \\
5-6 \text { of the } \\
\text { TP53 } \\
\text { gene }\end{array}$ & $\begin{array}{l}\text { f-TGTTCACTTGTGCCCTGACT } \\
\text { r-TTAACCССTCCTCCCAGAGA }\end{array}$ & \multirow{3}{*}{$\begin{array}{l}1 \text { cycle of } \\
\text { denaturation }(2 \mathrm{~min} \\
\left.\text { at } 94^{\circ} \mathrm{C}\right), 20 \text { cycles } \\
\text { of denaturation } \\
\left(94^{\circ} \mathrm{C} \text { for } 30 \mathrm{~s}\right) \text {, } \\
\text { annealing }\left(63^{\circ} \mathrm{C} \text { for }\right. \\
45 \mathrm{~s} \text {, with }-0.5^{\circ} \mathrm{C} \\
\text { per cycle, and } \\
\text { extension }\left(72^{\circ} \mathrm{C} \text { for }\right. \\
1 \mathrm{~min}) \text {, followed by } \\
30 \text { cycles of } \\
\text { denaturation }\left(94^{\circ} \mathrm{C}\right. \\
\text { for } 30 \mathrm{~s}) \text {, annealing } \\
\left(60^{\circ} \mathrm{C} \text {, } 45 \mathrm{~s}\right) \text {, } \\
\text { extension }\left(72^{\circ} \mathrm{C} \text { for }\right. \\
1 \text { min), and a final } \\
\text { extension cycle of } \\
72^{\circ} \mathrm{C} \text { for } 10 \mathrm{~min} \text {. }\end{array}$} & $467 \mathrm{bp}$ \\
\hline $\begin{array}{l}\text { Exon } 7 \text { of } \\
\text { the TP53 } \\
\text { gene }\end{array}$ & $\begin{array}{l}\text { f-CTTGCCACAGGTCTCCCCAA } \\
\text { r- } \\
\text { AGGGGTCAGAGGCAAGCAGA }\end{array}$ & & $237 \mathrm{bp}$ \\
\hline $\begin{array}{l}\text { Exons } \\
8-9 \text { of the } \\
\text { TP53 } \\
\text { gene }\end{array}$ & $\begin{array}{l}\text { f-TTGGGAGTAGATGGAGCCT } \\
\text { r-AGTGTTAGACTGGAAACTTT }\end{array}$ & & $445 \mathrm{bp}$ \\
\hline
\end{tabular}

Table 1: The PCR amplification protocols for direct sequencing.

DNA sequencing results were analyzed using ChromasPro version 1.7.4 and CodonCode Aligner version 4.2.7 softwares. All DNA sequence results were compared with the LOVD and UMD databases to examine the presence of new mutations. Changes in base sequence were confirmed by reverse sequencing.

\section{Results}

\section{Characteristics of the study population}

The study comprised 249 CRC patients first diagnosed with CRC in the period 2012-2014. Adenocarcinoma was the predominant tumor type among these patients, and $55.82 \%$ of the cases were well and moderately differentiated adenocarcinoma. All tumors were staged using TNM criteria: stage I; 16 cases (6.4\%); stage II; 86 cases $(34.5 \%)$; stage III; 108 cases $(43.4 \%)$ and stage IV; 39 cases (15.7\%). The localization of tumors were: rectum; 115 cases (47.7\%); colon; 48 cases (19.3\%); cecum; 18 cases (7.5\%); sigmoid; 57 cases $(22.9 \%)$ and rectosigmoid; 11 cases (4.6\%). Unfortunately, preliminary clinical investigation on early stages of CRC development was not done for the majority of these patients.

Among CRC patients there were 32 patients (12.9\%) with early cancer development (28-50 yrs). 10 patients (4.0\%) had close relatives afflicted by different types of cancer, including family history of lung cancer; breast cancer; cervical cancer; liver cancer; nasopharyngeal cancer and colorectal cancer. In this cohort there were 15 women and 17 men. The mean age of patients with early onset cancer was $40.66 \pm$ 6.64 (for males $-38.24 \pm 7.78$, and for females $-43.40 \pm 4.38$ ). Ethnic distribution among patients with early CRC onset was as follows: 21 Kazakh, 7 Russian, 3 Uighur and 1 Ukrainian.

\section{Investigation of early cancer onset and suspected familial colorectal cancer cases}

For investigation of patients with early onset CRC and suspected family history we examined the clinical symptoms for the choice of genes for analysis, and the following genetic regions were investigated by direct sequencing: 1) APC (967-1386, and 1286-1513 codons in exon 15); 2) MLH1 (exons 8 and 16); 3) MSH2 (exon 7); 4) TP53 (exons 5-9).

The direct sequencing of TP53 exons 5-9 did not show any changes in the coding sequences, but a heterozygous nucleotide replacement was detected in intron $9($ c. $993+12 \mathrm{~T}>\mathrm{C})$ for female 1967 with stage III rectal cancer (T3NxMo) (Figure 1a) and in intron 4 (c.376-19C $>\mathrm{T}$, Figure 1b) in another patient (female 1983with Stage III T4NxMo, rectal cancer). Another female (\#1969) with Stage II (T4NoMo) rectal cancer, demonstrated a nucleotide replacement in exon 8 of MLH1 A655G (Ile219Val, rs1799977) (Figure 1c). The nucleotide replacement in MLH1 intron 15 (c.1732-90C >A) (Figure 1d) was detected in 15 patients. A missense mutation (rs5028341) was detected in exon 7 of another mismatch repair gene MSH2 - C1168T (Leu390Phe) (Figure 1e). This nucleotide substitution was in the heterozygous state in one male patient (\#1975) with, Stage IV rectal cancer $(\mathrm{T} 4 \mathrm{NxM}+)$.

Three types of mutations were identified in the exon 15 of APC the gene in patients with early CRC development; these included a nonsense G4479A mutation (Thr1493Thr, rs41115) (Figures $1 \mathrm{f}$ and g), missense G3949C mutation (Glu1317Gln, rs1801166) (Figure 1h), and a micro deletion 3613delA (Ser1205fs) (Figure 1i). The APC G4479A polymorphism genotypes distribution in our patients with early onset cancer was as follows: G4479G - 9 (32.14\%); G4479A-2 (7.14\%); A4479A-17(60.71\%). The APC G3949C replacement was detected in the heterozygous state in only one patient (female, 1969, Stage II rectal cancer (T4NoMo). It should be noted that this patient also had a G4479A mutation in the APC gene and a mutation in MLH1 gene (G655A (Ile219Val)). The single base pair deletion, c.3613delA, which 
Citation: Djansugurova L, Zhunussova G, Khussainova E, Iksan O, Afonin G, et al. (2014) Screening the APC, MLH1, MSH2 and TP53 Mutations in Patients with Early Onset of Colorectal Cancer. J Carcinog Mutagen 5: 197. doi:10.4172/2157-2518.1000197

Page 4 of 9

is located in exon 15 of APC gene, was found in the heterozygous state

in two patients with adenomatous polyposis. Both patients are male siblings and were born in 1984 and 1986 (Figure 2).

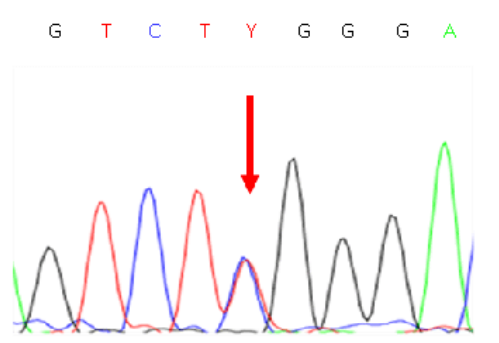

a) c. $993+12 \mathrm{~T}>\mathrm{C}$ substitution (rs 1800899) in intron 9 of TP53 gene. Heterozygous $\mathrm{T} / \mathrm{C}(\mathrm{Y})$.

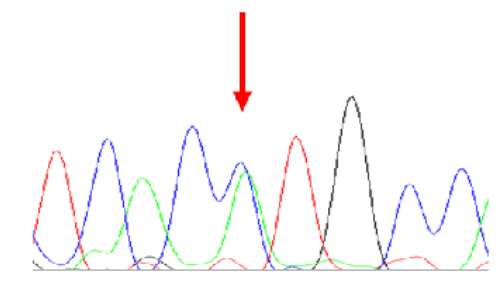

d) c.1732-90C $>$ A substitution in intron 15 of MLH1 gene. Hetrozygous C/A (H).

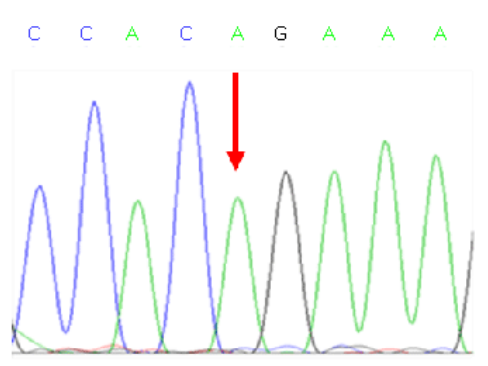

d) c.1732-90C $>$ A substitution in intron 15 of $M L H 1$ gene. Hetrozygous C/A (H).

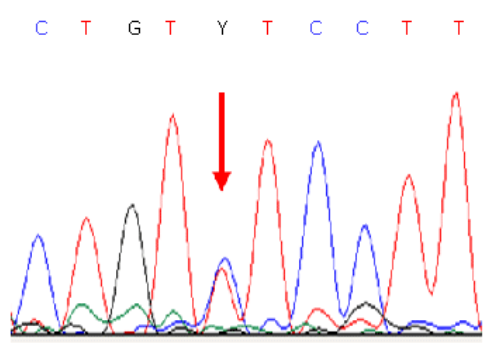

b) c.376-19C $>\mathrm{T}$ substitution in intron 4 of TP53 gene. Heterzygous $\mathrm{C} / \mathrm{T}$ (Y).

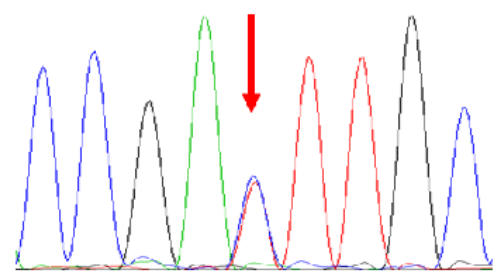

e) c. $1168 \mathrm{C}>\mathrm{T}$ substitution (rs5028341, p.Leu390Phe) in exon 7 of $M S H 2$ gene. Heterozygous C/T (Y).

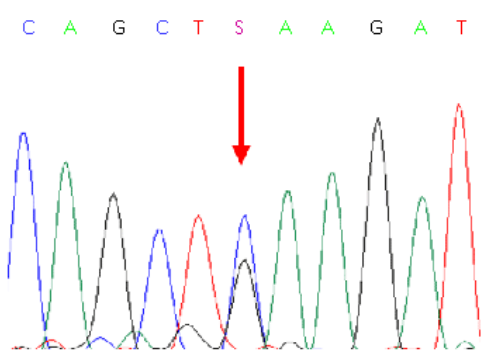

e) c. $1168 \mathrm{C}>\mathrm{T}$ substitution (rs5028341, p.Leu390Phe) in exon 7 of $M S H 2$ gene. Heterozygous $\mathrm{C} / \mathrm{T}(\mathrm{Y})$.

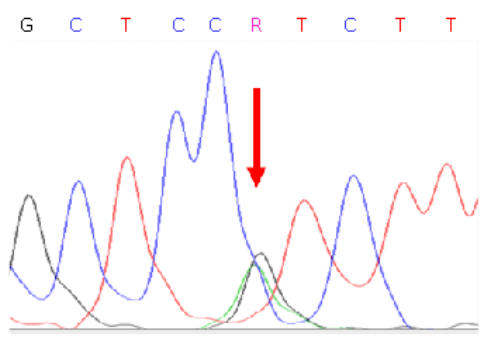

c) c. $655 \mathrm{~A}>\mathrm{G}$ substitution i(rs 1799977 , Ile219Val) in exon 8 of $M L H 1$ gene. Heterozygous $\mathrm{A} / \mathrm{G}(\mathrm{R})$.

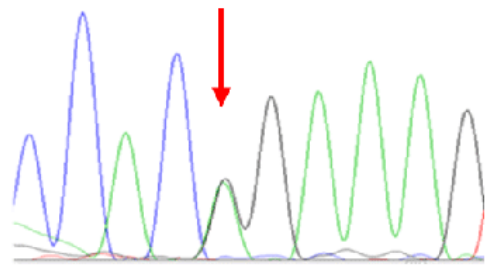

f) c.4479G $>\mathrm{A}$ (rs4115, p. Thr1493) in exon 15 of $A P C$ gene. Hetorzygous $\mathrm{G} / \mathrm{A}(\mathrm{R})$.

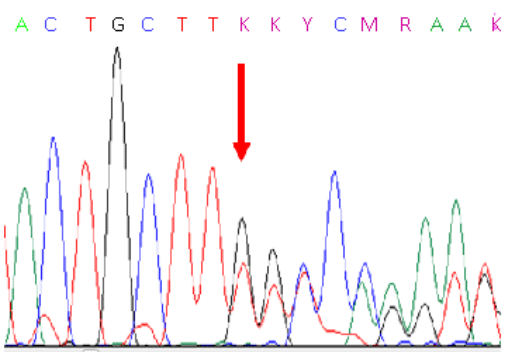

f) c.4479G $>\mathrm{A}$ (rs4115, p. Thr 1493) in exon 15 of $A P C$ gene. Hetorzygous $\mathrm{G} / \mathrm{A}(\mathrm{R})$.

Figure 1: DNA sequencing results. 
Citation: Djansugurova L, Zhunussova G, Khussainova E, Iksan O, Afonin G, et al. (2014) Screening the APC, MLH1, MSH2 and TP53

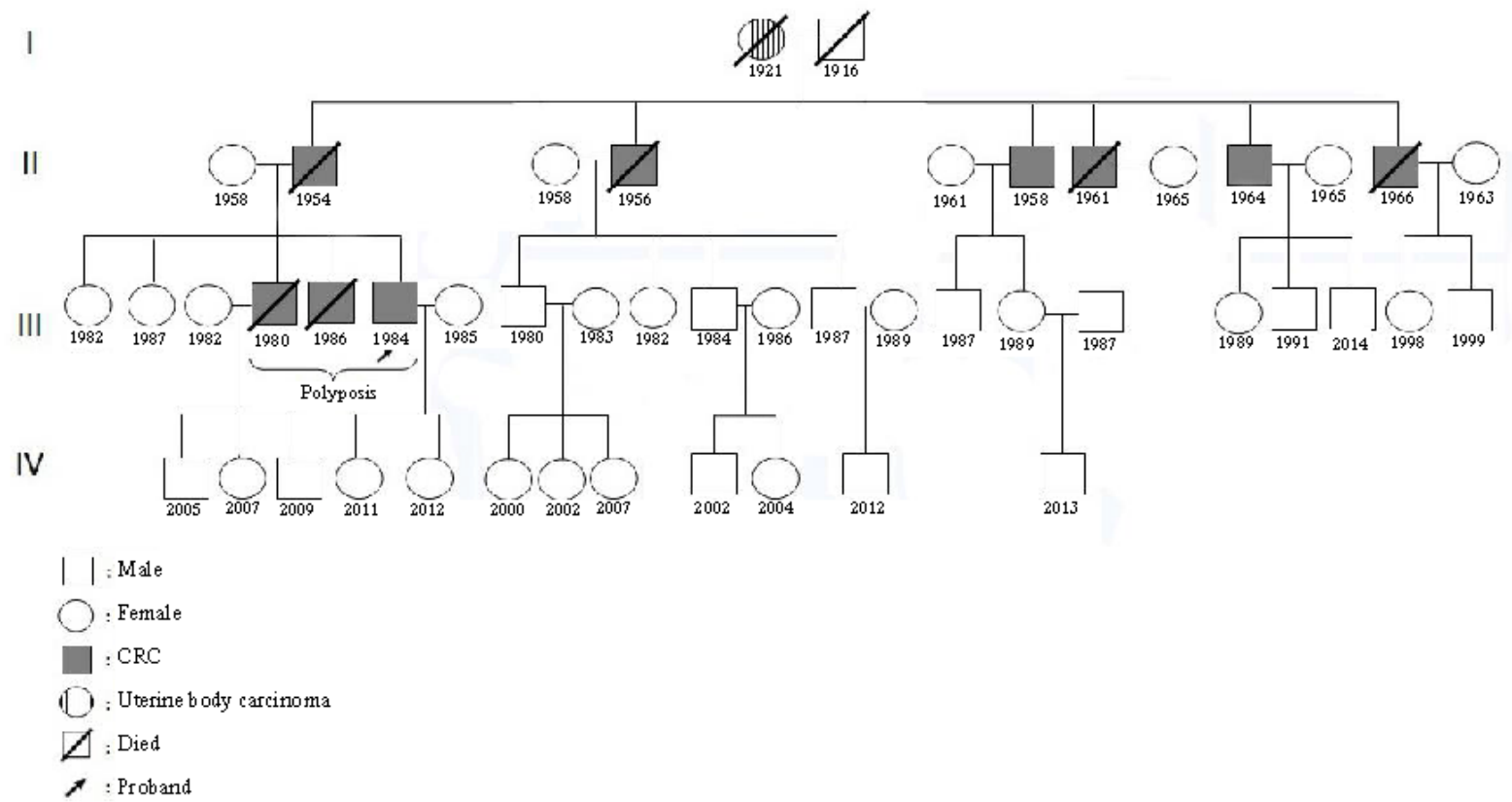

Figure 2: Pedigree of family with colorectal cancer.

\section{Discussion}

The incidence of colorectal cancer increases with age. It is well known that the mean age for development of sporadic CRC is about 70 years. Early onset of CRC indicates an increased likelihood of genetic predisposition and hereditary forms contributing to about $3-5 \%$ of all colorectal cancers [1]. The most common hereditary form is Lynch syndrome. Three out of every 100 colon cancers are caused by Lynch syndrome. People with Lynch syndrome may develop colorectal cancer at a young age (before age 50) and they generally have a family history of colon cancer or other related cancers (endometrial, ovarian, liver, kidney, stomach, small intestine cancers). FAP is characterized by the development of polyps that eventually leads to development of colorectal cancer [1]. Variance in disease expression has been described and typified by fewer colonic and rectal adenomas (usually fewer than 100), a later age of onset and a reduced likelihood of colorectal cancer development. The population incidence of FAP is approximately 1:7000 and affects both sexes equally.

Early onset CRC in young adults used to be considered a rare occurrence, but many recent reports suggest not only that early onset CRC could be as high as $8 \%$ of all CRCs, but also that it might be increasing [18]. Similarly, it is a common belief that early onset CRC is mainly related to hereditary forms, especially to Lynch syndrome. In our study, the onset of cancer before age 50 was diagnosed for $12.9 \%$ of all CRC patients ( 32 out of 249 patients). The presence of a familial background of cancer was confirmed in 10 (31.3\%) of the 32 cases while hereditary forms of CRC were confirmed in 3 (9.4\%) patients of the present cohort.

In the patients with early-onset CRC and a family history of CRC we investigated the key CRC genes that are the most common target for mutation. The choice of regions for the direct sequencing was done taking into account the correlations of mutations with familial syndromes. Unfortunately, most of our suspected familial cases were diagnosed at a very late stage of the disease, and there was very little known about the primarily disease symptoms. Only two patients with polyposis were detected in this group. Therefore we decided to investigate patients with early onset CRC for all chosen key CRC gene mutation targets. Table 2 presents summarizing DNA sequencing results of 32 patients with CRC development before age 50, including 10 patients with family history of cancer.

Germline mutations in the DNA mismatch repair genes MSH2 and MLH1, which are the two "major" genes associated with hereditary nonpolyposis colon cancer account for more than $90 \%$ of cases with Lynch syndrome. MSH2 and MLH1 mutations occur in 22- $86 \%$ of families meeting the international diagnostic criterial for the disorder (Amsterdam I). Among families not meeting these criteria, less than $30 \%$ showed mutations [9-11,15,17]. All exons of MLH1 and MSH2 genes contain pathogenic mutations. However, from the literature the highest mutation prevalence occurs in exon 16 of the MLH1 gene and in exon 7 of the MSH2 gene. Also the higher mutation prevalence was in exon 2, exon 6, exon 8 of MLH1 and in exon 3, exon 5, exon 11 of MSH2 [5,9].

In our study, the most frequent change observed in 15 patients $(53.57 \%)$ with early cancer onset was the nucleotide replacement in intron 15 of MLH1 (c.1732-90C >A). We could not find any reference to this change in the literature.

One patient suffering from moderately differentiated carcinoma of the rectum ( $45 \mathrm{yrs}$ ) was heterozygous for the nucleotide replacement in MLH1 exon 8-c.655G>A (Ile219Val, rs1799977). The MLH1 c. $655 \mathrm{~A}>\mathrm{G}$ mutation was reported 224 times in the InSiGHT database and 251 times in the LOVD database. The significance of the sequence alteration is controversial as the c. $655 \mathrm{~A}>\mathrm{G}$ variant is considered a polymorphism (dbSNP1799977) and was reported in HapMap 
database (www.hapmap.org). MLH1 c.655A $>\mathrm{G}$ is in a conserved region of exon 8 , and both alleles result in non-polar and $\mathrm{pH}$-neutral amino acids. Functional analyses suggest that the variant has efficient DNA repair activity [19-20] and binding properties to PMS2 are similar to the wild type [21]. The study of families with Lynch syndrome from Finland discovered that $42 \%$ were informative for the MLH1 codon $219 \mathrm{~A} / \mathrm{G}$ polymorphism showing the unbalanced mRNA expression and absence of normal A allele expression [22]. Reduced MLH1 protein associated with c.655A $>\mathrm{G}$ polymorphism was also documented among sporadic CRCs in Korean population [23]. Many studies reported to occur of MLH1 c.655A $>\mathrm{G}$ in association with CRC risk at frequency $\geq 1 \%$ [24-26]. This variant is not only involved in colorectal cancer, but also in some other types of cancers. MLH1 c. $655 \mathrm{~A}>\mathrm{G}$ is associated with an almost fivefold increased risk of ulcerative colitis [27], and 6- to 16-fold increased risk of acute lymphoblastic leukemia when combined with known genotypes of increased susceptibility to leukemia [28]. The variant may be associated with the young-onset of lung cancer, especially in histological squamous cell type [29], and may influence the onset of prostate cancer [30]. Also the Ile219Val polymorphism may be linked with greater mutation frequency (deletions or substitutions rather than insertions) [31]. However, the recent qualitative classification by calibration in silico Tools defined the MLH1 (p.Ile219Leu) missense substitution as non-pathogenic [32]. Some studies also show no association between MLH1 Ile219Val polymorphisms and hereditary colorectal cancer development [33,34]. Our results suggest a possible role of MLH1 c.655A $>\mathrm{G}$ polymorphism in the early onset of CRC. But it remains to be further investigated with larger sample sizes.

We registered the MSH2-c.1168C $>\mathrm{T}$ (Leu390Phe, rs5028341) mutation at only one patient with early CRC onset. This mutation might cause a polarity change at the margin of the interaction region of MSH2 [35]. Although this mutation was first reported in 1996, its function is still controversial [36]. Search in the InSiGHT database and the original papers showed that this substitution occurs in about $80 \%$ in East Asian populations, including Chinese Han, Japanese, Korean and Singaporean. However, there were no evidence of MSH2 c. $1168 \mathrm{C}>\mathrm{T}$ association with hereditary forms of CRC in Caucasians, including German population [32,37]. But Japanese cancer patients with family histories of colorectal and endometrial carcinoma demonstrate the $\mathrm{MSH} 2 \mathrm{c} .1168 \mathrm{C}>\mathrm{T}$ [38]. The strong correlation with early onset of CRC and gastric cancer was found at Chinese population $[39,40]$. Chinese patients suffering from Lynch syndrome demonstrate the MSH2 c. $1168 \mathrm{C}>\mathrm{T}$ substitution with $4 \%$ frequency [41]. We consider that investigations into the relationship between $\mathrm{MSH} 2$ c. $1168 \mathrm{C}>\mathrm{T}$ and $\mathrm{CRC}$ risk should to be continued in casecontrol studies and Lynch syndrome families in Asian populations.

Mutations in the APC gene cause both classic and attenuated familial adenomatous polyposis (FAP). Most of the mutations (germline or somatic) in APC gene occur in exon 15 comprises more than $75 \%$ of coding sequence $[3,4,42-44]$. The most common germline mutations occur at codons 1061 and 1309 (5bp deletions) and account for $17 \%$ and $11 \%$ germline APC mutations, respectively. The region between codons 1286 and 1513 is known as the "mutation cluster region" (MCR), and many of the identified APC mutations occur in this segment of the gene [45]. About $90 \%$ of all mutations in the APC gene lead to truncations of the APC protein product. Dysfunction of the APC gene causes the accumulation of $\beta$-cathenin and the expression of genes that promote cell division.

By screening of exon 15 of APC gene (967-1386, and 1286-1513 codons covered regions) we observed three types of mutation in patients with early CRC onset: nonsense mutation - G4479A (p.Thr1493Thr, rs41115), missense mutation - G3949C (p.Glu1317Gln, rs1801166), and microdeletion 3613delA (p.Ser1205fs).

APC 4479 G>A polymorphism (p.Thr1493Thr, rs41115) is found in a variety of tumors, especially in FAP families [44-47]. In coding region of APC, at the position 4479 substitution G>A is a neutral polymorphism and is known as silent polymorphism. Little is known about clinical significance of APC $4479 \mathrm{G}>\mathrm{A}$ polymorphism, which does not lead to amino acid replacement. However, GA heterozygous genotype at the position 4479 was associated with significantly decreased CRC risk [45], and the wild genotype (G/G) appeared to have a protective effect, decreasing the CRC risk of moderate/severe disease [48]. Our study revealed that the APC 4479 G $>$ A polymorphism was most common for Kazakhstan patients with early CRC onset. 17 individuals were homozygous by mutant A allele, and 2 patients were heterozygous. The prevalence of mutant homozygous (A/A - 60.71\%) suggests that A allele can define the predisposition to early CRC onset. Of course this assumption needs further verification.

Another, missense mutation in exon 15 of APC - G3949C (p.Glu1317Gln, rs1801166) was detected in one patient (45 y.o.) with rectum cancer in heterozygous state. The APC Glu1317Gln missense variant was first described by White et al. [49] in two of four siblings in an Ashkenazi Jewish colorectal cancer family. APC c.3949G $>$ A polymorphism results in a change in APC ESE (exon splice enhancer) motif structure and is likely to have more influence on differential mRNA splicing, which is could result in the creation of mRNA species that would result in proteins incapable of being fully functionally active. It has been suggested that Glu1317Gln affects APC function by subtle effects on $\beta$-catenin sequestration or degradation [50]. In fact, most germline and somatic mutations result in the loss or alteration of $\beta$-catenin binding, as most of these point mutations occur at $\mathrm{CpG}$ dinucleotides, generating stop codons by a C-to-T transition in a CGA sequence. The clinical significance of the c.3949G $>\mathrm{C}$ mutation is questionable.

The expected result of these changes would be a mild phenotype consistent with the notion that haploinsufficiency can stimulate the disease development [48]. APC c.3949G $>$ A with changing the functional role of the APC protein can influence the risk of developing polyposis. This mutation has been associated with FAP $[42,48,51]$. The c.3949G $>$ C mutation is significantly associated with colorectal adenomas and carcinomas [42,52]. Some study showed that there was no association between Glu1317Gln and colorectal cancer [53-55].

A common from the literature 5-base-pair frameshift deletion at codon 1061 and 1309 of APC gene [3,4,42,43] was not identified in our patients. But another frameshift mutation, the single base pair deletion, c.3613delA, which is located in exon 15 of APC gene, was found in heterozygous state in two patients with adenomatous polyposis. Both patients represent one family history of CRC (Figure 2). 
Citation: Djansugurova L, Zhunussova G, Khussainova E, Iksan O, Afonin G, et al. (2014) Screening the APC, MLH1, MSH2 and TP53 Mutations in Patients with Early Onset of Colorectal Cancer. J Carcinog Mutagen 5: 197. doi:10.4172/2157-2518.1000197

Page 7 of 9

\begin{tabular}{|c|c|c|c|c|c|}
\hline Gene & Exon/Intron & Nucleotide position & $\begin{array}{l}\text { Consequence of } \\
\text { mutation }\end{array}$ & Affected patients & LOVD database \\
\hline$A P C$ & ex 15 & $\begin{array}{l}\text { c.3613delA } \\
\text { Heterozygous }\end{array}$ & p.Ser1205fs & 2 FAP patients (males, sibs) & $\begin{array}{l}\text { Reported } 1 \text { time. The mutation is associated } \\
\text { with FAP [56]. }\end{array}$ \\
\hline$A P C$ & ex 15 & $\begin{array}{l}\text { c.3949G }>C \\
\text { Heterozygous }\end{array}$ & $\begin{array}{l}\text { p.Glu1317Gln } \\
\text { rs1801166 }\end{array}$ & $\begin{array}{l}1 \text { (female, } 1969, \text { rectum } \\
\text { cancer, Stage II T4NoMo) }\end{array}$ & $\begin{array}{l}\text { Reported } 16 \text { times. The mutation is } \\
\text { significantly associated with FAP and CRC } \\
{[42,48,49,51,52] \text {. }}\end{array}$ \\
\hline$A P C$ & ex 15 & c. $4479 \mathrm{G}>\mathrm{A}$ & p.Thr1493Thr, rs41115 & $\begin{array}{l}2 \text { heterozygous and } \\
17 \text { homozygous }\end{array}$ & $\begin{array}{l}\text { Reported } 10 \text { times. The mutation is } \\
\text { associated with some cancers of digestive } \\
\text { organs, including FAP [44-47]. }\end{array}$ \\
\hline MLH1 & i 15 & $\begin{array}{l}\text { c. } 1732-90 \mathrm{C}>\mathrm{A} \\
\text { Heterozygous }\end{array}$ & & 15 & No Reports \\
\hline MLH1 & ex 8 & $\begin{array}{l}\text { c. } 655 \mathrm{G}>\mathrm{A} \text {, rs } 1799977 \\
\text { Heterozygous }\end{array}$ & p. Ile219Val & $\begin{array}{l}1 \text { (female, } 1969, \text { rectum } \\
\text { cancer, Stage II T4NoMo) }\end{array}$ & $\begin{array}{l}\text { Reported } 251 \text { times. The mutation is } \\
\text { associated with Lynch syndrome [22], } \\
\text { sporadic CRC [23-26], ulcerative colitis [27], } \\
\text { lymphoblastic leukaemia [28], lung cancer } \\
\text { [29], prostate cancer [30]. }\end{array}$ \\
\hline MSH2 & ex 7 & $\begin{array}{l}\text { c. } 1168 \mathrm{C}>\mathrm{T}, \\
\text { rs } 5028341 \\
\text { Heterozygous }\end{array}$ & p.Leu390Phe & $\begin{array}{l}1 \text { (male, } 1975, \quad \text { rectum } \\
\text { cancer, Stage IV T4NxM+) }\end{array}$ & $\begin{array}{l}\text { Reported } 39 \text { times. The mutation is } \\
\text { associated with early onset of CRC and } \\
\text { gastric cancer [39, 40], Lynch syndrome [41]. }\end{array}$ \\
\hline TP53 & i 9 & $\begin{array}{l}\text { c. } 993+12 T>C \text {, rs } 1800899 \\
\text { Heterozygous }\end{array}$ & & $\begin{array}{l}1 \text { (female, 1967, rectum } \\
\text { cancer, Stage III T3NxMo) }\end{array}$ & No Reports \\
\hline TP53 & i 4 & $\begin{array}{l}\text { c. } 376-19 \mathrm{C}>\mathrm{T} \\
\text { Heterozygous }\end{array}$ & & $\begin{array}{l}1 \text { (female, 1983, rectum } \\
\text { cancer, Stage III T4NxMo) }\end{array}$ & No Reports \\
\hline
\end{tabular}

Table 2: DNA sequencing results in early CRC onset patients.

Previously, this single base pair deletion, c.3613delA, was the first reported in Polish families with FAP but only one patient had this mutation [56]. Certainly this deletion (c.3613delA) at codon 1205 leads to truncation of the APC protein product. Carrying of this mutation, which definitely disrupt the APC function, can cause familial adenomatous polyposis in the result of loss of heterozygosity in somatic cells. Interestingly, that both brothers have also the change in 15 intron of MLH1 gene (c.1732-90C >A).

The analysis of suspected familial cases registered 1 patient (female, 1969, rectum cancer, St.II T4NoMo) simultaneously having 4 changes of the identified 8 (table 2): MLH1 polymorphisms in exon 8 (c. 655A $>$ G/Ile219Val, rs1799977) and intron 15 (c.1732-90C >A), APC polymorphisms of exon 15-c.3949G>A (p.Glu1317Gln, rs1801166) and 4479G $>$ A (p.Thr1493Thr, rs41115). There is an evidence of CRC and cervical cancer in family history of this patient.

Tumor suppressor gene TP53, regulating the cell cycle, apoptosis, and genome stability, is one of the most frequently mutated genes in human cancers. The most common mutations are single base substitutions that alter protein function. Some of the mutations being oncogenic confer gain-of-function properties. In CRC more than 50\% of mutations occur in TP53 gene, and most of them are mutations in exons 5-9. Inactivating mutations in 5-9 exons of TP53, which include four highly conserved domains, play an important role in the clinical outcome of colon cancer [6-7,57]. In our study two types of nucleotide replacement were detected in intron 4 (c.376-19C $>$ T) and intron 9 (c. $993+12 \mathrm{~T}>\mathrm{C}$ ) of TP53 at two patients in the result of screening of 32 patients with early CRC onset. Nothing known about significance of these changes.

Summarizing, we suggest a possible role of MLH1 c.655A $>\mathrm{G}$ (Ile219Val, rs1799977), MSH2 c.1168C >T (Leu390Phe, rs5028341), APC 4479 G>A (p.Thr1493Thr, rs41115), and APC - G3949C (p.Glu1317Gln, rs1801166) polymorphisms in the susceptibility to early onset of CRC. Additionally, multiple genetic changes in MLH1 and APC genes can predispose the early development of colon or rectum cancer in patients with family history of CRC. But it remains to be further investigated with additional samples. Deletion at codon 1205 (c.3613delA) of APC gene seems to be differentially associated with early-onset cases depending on having a polyposis and family history of CRC.

Concerning strengths and limitations, our study could be considered as the first to thoroughly evaluate CRC susceptibility variants in early-onset patients from Kazakhstan in order to identify if any of them could be more predominantly linked to CRC risk before age 50 . On the other hand, it should be also pointed out that our results should be considered cautiously due to the relative small number of early-onset CRC patients included. Also, since our results should be formally considered not statistically significant when applying multiple testing correction, additional studies in other CRC cohorts are needed to confirm the potential association of susceptibility variants with early-onset CRC. Perhaps further study of patients with early CRC onset in ethnically different populations will provide statistically reliable data on the involvement of mutations, 
which were detected in patients from Kazakhstan, in the genetic predisposition to the development of colorectal cancer.

\section{Acknowledgements}

This work was supported by grant N.0067/GF of Committee of Science, Ministry of Education and Science of Republic of Kazakhstan. M. Iqbal Parker was funded by grants from the International Centre for Genetic Engineering and Biotechnology, the Medical Research Council of South Africa and the University of Cape Town.

We are sincerely grateful to all patients participating in this study. We are also grateful to the doctors of Almaty Oncology Centre for the help in collecting biosamples and histological testing. Very special thanks are expressed to the rector of the Asfendiyarov Kazakh National Medical University Aikan Akanov and Head of Oncological Department Bakhyt Kh. Khaidarov who managed the research and did the ethical attestation.

\section{References}

1. Brenner H, Kloor M, Pox CP (2014) Colorectal Cancer. Lancet 383: 1490-1502.

2. Sjoblom T, Jones S, Wood LD, Parsons DW, Lin J, et al. (2006) The Consensus Coding Sequences of Human Breast and Colorectal Cancers. Science 314: 268-274.

3. Beroud C, Soussi T (1996) APC gene: database of germline and somatic mutations in human tumors and cell lines. Nucleic Acids Res 24: 121-124.

4. Fearnhead NS, Britton MP, Bodmer WF (2001) The ABC of APC. Hum Mol Genet 10: 721-733.

5. Mitchell RJ, Farrington SM, Dunlop MG, Campbell H (2002) Mismatch repair genes hMLH1 and hMSH2 and colorectal cancer: a HuGE review. Am J Epidemiol 156: 885-902.

6. Park JY, Mitrou PN, Keen J, Dahm CC, Gay LJ, et al. (2010) Lifestyle factors and p53 mutation patterns in colorectal cancer patients in the EPIC-Norfolk study. Mutagenesis 25: 351-358.

7. Robles AI, Harris CC (2010) Clinical outcomes and correlates of TP53 mutations and cancer. Cold Spring Harb Perspect Biol 2: a001016.

8. Naccarati A, Polakova V, Pardini B, Vodickova L, Hemminki K, et al. (2012) Mutations and polymorphisms in TP53 gene--an overview on the role in colorectal cancer. Mutagenesis 27: 211-218.

9. Li D, Hu F, Wang F, Cui B, Dong X, et al. (2013) Prevalence of pathological germline mutation of hMLH1 and hMSH2 genes in colorectal cancer. PLoS One

10. Johns LE, Houlston RS (2001) A systematic review and meta-analysis of familial colorectal cancer risk. Am J Gastroenterol 96: 2992-3003.

11. Lynch HT, de la Chapelle A (2003) Hereditary colorectal cancer. N Engl J Med 348: 919-932.

12. de la Chapelle A (2004) Genetic predisposition to colorectal cancer. Nat Rev Cancer 4: 769-780.

13. Merg A, Lynch HT, Lynch JF, Howe JR (2005) Hereditary colorectal cancer-part II. Curr Probl Surg 42: 267-333.

14. Strate LL, Syngal S (2005) Hereditary colorectal cancer syndromes. Cancer Causes Control 16: 201-213.

15. Jasperson KW, Tuohy TM, Neklason DW, Burt RW (2010) Hereditary and familial colon cancer. Gastroenterology 138: 2044-2058.

16. Bianchi F, Raponi M, Piva F, Viel A, Bearzi I, et al. (2011) An intronic mutation in MLH1 associated with familial colon and breast cancer. Fam Cancer 10: 27-35.

17. Migliore L, Migheli F, Spisni R, Coppedè F (2011) Genetics, cytogenetics, and epigenetics of colorectal cancer. J Biomed Biotechnol 2011: 792362.

18. Siegel R, DeSantis C, Virgo K, Stein K, Mariotto A, et al. (2012) Cancer treatment and survivorship statistics, 2012. CA Cancer J Clin 62: 220-241.
19. Trojan J, Zeuzem S, Randolph A, Hemmerle C, Brieger A, et al. (2002) Functional analysis of hMLH1 variants and HNPCC-related mutations using a human expression system. Gastroenterology 122: 211-219.

20. Raevaara TE, Korhonen MK, Lohi H, Hampel H, Lynch E, et al. (2005) Functional significance and clinical phenotype of nontruncating mismatch repair variants of MLH1. Gastroenterology 129: 537-549.

21. Kondo E, Suzuki H, Horii A, Fukushige S (2003) A yeast two-hybrid assay provides a simple way to evaluate the vast majority of hMLH1 germ-line mutations. Cancer Res 63: 3302-3308.

22. Renkonen E, Zhang Y, Lohi H, Salovaara R, Abdel-Rahman WM, et al. (2003) Altered expression of MLH1, MSH2, and MSH6 in predisposition to hereditary nonpolyposis colorectal cancer. J Clin Oncol 21: 3629-3637.

23. Kim JC, Roh SA, Koo KH, Ka IH, Kim HC, et al. (2004) Genotyping possible polymorphic variants of human mismatch repair genes in healthy Korean individuals and sporadic colorectal cancer patients. Fam Cancer 3: 129-137.

24. Listgarten J, Damaraju S, Poulin B, Cook L, Dufour J, et al. (2004) Predictive models for breast cancer susceptibility from multiple single nucleotide polymorphisms. Clin Cancer Res 10: 2725-2737.

25. Campbell PT, Curtin K, Ulrich CM, Samowitz WS, Bigler J, et al. (2009) Mismatch repair polymorphisms and risk of colon cancer, tumour microsatellite instability and interactions with lifestyle factors. Gut 58: 661-667.

26. Nejda N, Iglesias D, Moreno Azcoita M, Medina Arana V, GonzálezAguilera JJ, et al. (2009) A MLH1 polymorphism that increases cancer risk is associated with better outcome in sporadic colorectal cancer. Cancer Genet Cytogenet 193: 71-77.

27. Bagnoli S, Putignano AL, Melean G, Baglioni S, Sestini R, et al. (2004) Susceptibility to refractory ulcerative colitis is associated with polymorphism in the hMLH1 mismatch repair gene. Inflamm Bowel Dis 10: 705-708.

28. Mathonnet G, Krajinovic M, Labuda D, Sinnett D (2003) Role of DNA mismatch repair genetic polymorphisms in the risk of childhood acute lymphoblastic leukaemia. Br J Haematol 123: 45-48.

29. An Y, Jin G, Wang H, Wang Y, Liu H, et al. (2008) Polymorphisms in hMLH1 and risk of early-onset lung cancer in a southeast Chinese population. Lung Cancer 59: 164-170.

30. Fredriksson H, Ikonen T, Autio V, Matikainen MP, Helin HJ, et al. (2006) Identification of germline MLH1 alterations in familial prostate cancer. Eur J Cancer 42: 2802-2806.

31. Hutter P, Wijnen J, Rey-Berthod C, Thiffault I, Verkuijlen P, et al. (2002) An MLH1 haplotype is over-represented on chromosomes carrying an HNPCC predisposing mutation in MLH1. J Med Genet 39: 323-327.

32. Thompson BA, Greenblatt MS, Vallee MP, Herkert JC, Tessereau C, et al. (2013) Calibration of multiple in silico tools for predicting pathogenicity of mismatch repair gene missense substitutions. Hum Mutat 34: 255-265.

33. Mei Q, Yan HL, Ding FX, Xue G, Huang JJ, et al. (2006) Singlenucleotide polymorphisms of mismatch repair genes in healthy Chinese individuals and sporadic colorectal cancer patients. Cancer Genet Cytogenet 171: 17-23.

34. Blanco I, Gonzalez S, Guino E, Capella G, Moreno V (2008) Polymorphisms in DNA repair genes and familial colorectal cancer risk. J Clin Oncol (Meeting Abstracts) 26.

35. Chen CH, Huang RL, Yu MS, Wong LJ, Chao TF, et al. (2001) Hereditary nonpolyposis colorectal cancer with gynecologic malignancies: report of two families in Taiwan. J Formos Med Assoc 100: 269-273.

36. Konishi M, Kikuchi-Yanoshita R, Tanaka K, Muraoka M, Onda A, et al. (1996) Molecular nature of colon tumors in hereditary nonpolyposis colon cancer, familial polyposis, and sporadic colon cancer. Gastroenterology 111: 307-317.

37. Mangold E, Pagenstecher C, Friedl W, Mathiak M, Buettner R, et al. (2005) Spectrum and frequencies of mutations in MSH2 and MLH1 identified in 1,721 German families suspected of hereditary nonpolyposis colorectal cancer. Int J Cancer 116: 692-702. 
Citation: Djansugurova L, Zhunussova G, Khussainova E, Iksan O, Afonin G, et al. (2014) Screening the APC, MLH1, MSH2 and TP53 Mutations in Patients with Early Onset of Colorectal Cancer. J Carcinog Mutagen 5: 197. doi:10.4172/2157-2518.1000197

Page 9 of 9

38. Banno K, Susumu N, Nozawa S, Sugano K (2004) Met688Ile and Leu390Phe of the MSH2 gene are not functional mutations, but polymorphisms in Japanese individuals. Cancer Genet Cytogenet 155: 92.

39. Fan Y, Liu X, Zhang H, Dai J, Zhang X, et al. (2006) Variations in exon 7 of the MSH2 gene and susceptibility to gastrointestinal cancer in a Chinese population. Cancer Genet Cytogenet 170: 121-128.

40. Zhang Y, Liu X, Fan Y, Ding J, Xu A, et al. (2006) Germline mutations and polymorphic variants in MMR, E-cadherin and MYH genes associated with familial gastric cancer in Jiangsu of China. Int J Cancer 119: $2592-2596$

41. Wei W, Liu F, Liu L, Li Z, Zhang X, et al. (2011) Distinct mutations in MLH1 and MSH2 genes in hereditary non-polyposis colorectal cancer (HNPCC) families from China. BMB Rep 44: 317-322.

42. Lamlum H, Al Tassan N, Jaeger E, Frayling I, Sieber O, et al. (2000) Germline APC variants in patients with multiple colorectal adenomas, with evidence for the particular importance of E1317Q. Hum Mol Genet 9: 2215-2221.

43. Kwong LN, Dove WF (2009) APC and its modifiers in colon cancer. Adv Exp Med Biol 656: 85-106.

44. Cetta F, Dhamo A (2007) Inherited multitumoral syndromes including colorectal carcinoma. Surg Oncol 16 Suppl 1: S17-23.

45. Chen SP, Tsai ST, Jao SW, Huang YL, Chao YC, et al. (2006) Single nucleotide polymorphisms of the APC gene and colorectal cancer risk: a case-control study in Taiwan. BMC Cancer 6: 83.

46. Rocco A, Caruso R, Toracchio S, Rigoli L, Verginelli F, Catalano T, et al. (2006) Gastric adenomas: relationship between clinicopathological findings, Helicobacter pylori infection, APC mutations and COX-2 expression. Ann Oncol

47. Pizzi S, Azzoni C, Tamburini E, Bottarelli L, Campanini N, D'Adda T, et al. (2008) Adenomatous polyposis coli alteration in digestive endocrine tumours: Correlation with nuclear translocation of beta-catenin and chromosomal instability. Endocr Relat Cancer 15: 1013-1024.

48. Scott RJ, Crooks R, Rose L, Attia J, Thakkinstian A, et al. (2004) Germline Missense Changes in the APC Gene and Their Relationship to Disease. Hered Cancer Clin Pract 2: 81-91.
49. White S, Bubb VJ, Wyllie AH (1996) Germline APC mutation (Gln1317) in a cancer-prone family that does not result in familial adenomatous polyposis. Genes Chromosomes Cancer 15: 122-128.

50. Albuquerque C, Breukel C, van der Luijt R, Fidalgo P, Lage P, et al. (2002) The 'just-right' signaling model: APC somatic mutations are selected based on a specific level of activation of the beta-catenin signaling cascade. Hum Mol Genet 11: 1549-1560.

51. Frayling IM, Beck NE, Ilyas M, Dove-Edwin I, Goodman P, et al. (1998) The APC variants $\mathrm{I} 1307 \mathrm{~K}$ and E1317Q are associated with colorectal tumors, but not always with a family history. Proc Natl Acad Sci U S A 95: 10722-10727.

52. Popat S, Stone J, Coleman G, Marshall G, Peto J, et al. (2000) Prevalence of the APC E1317Q variant in colorectal cancer patients. Cancer Lett 149: 203-206.

53. Evertsson S, Lindblom A, Sun XF (2001) APC I1307K and E1317Q variants are rare or do not occur in Swedish colorectal cancer patients. Eur J Cancer 37: 499-502.

54. Rozek LS, Rennert G, Gruber SB (2006) APC E1317Q is not associated with Colorectal Cancer in a population-based case-control study in Northern Israel. Cancer Epidemiol Biomarkers Prev 15: 2325-2327.

55. Petrukhin L, Dangel J, Vanderveer L, Costalas J, Bellacosa A, et al. (1997) The I1307K APC mutation does not predispose to colorectal cancer in Jewish Ashkenazi breast and breast-ovarian cancer kindreds. Cancer Res 57: 5480-5484.

56. Plawski A, Lubiski J, Banasiewicz T, Paszkowski J, Lipinski D, et al. (2004) Novel germline mutations in the adenomatous polyposis coli gene in Polish families with familial adenomatous polyposis. J Med Genet 41: e11.

57. Akkiprik M, Ataizi-Celikel C, Dusunceli F, Sanmez O, Gulluoglu BM, et al. (2007) Clinical significance of p53, K-ras and DCC gene alterations in the stage I-II colorectal cancers. J Gastrointestin Liver Dis 16: 11-17. 